\title{
衝撃電圧によるアルミナ充てんエポキシ 樹脂の絶縁破壊特性
}

\begin{tabular}{|c|c|c|c|c|}
\hline 員 & 吉 & 村 & 昇 & (秋 \\
\hline 員 & 西 & 田 & 真 & (秋 \\
\hline 占 & & 成 & 隆 & (八庐I \\
\hline & & 文 & 敏 & （㳄 田 \\
\hline & & 昌 & & (東芝) \\
\hline
\end{tabular}

\section{1. まえがき}

一般に，エポキシ樹脂を電気絶縁材料として使用す る場合，樹脂単体での利用よりも種々の特性要求に合 せて無機柔粉末粒子を湿合して利用することが多い。 無機系粉末柆子の湿入は，機械的特性の改丵之同時に 材料費它低減できるという工業的利点を有しているた めである。無機系粉末粒子を混入したエポキシ樹脂の 機械的特性, 䚷電特性, 耐トラッキング性, 耐卜リー イング性および $V-t$ 特性については㭘討が加えられ ているが(1) (4)，電気絶縁材料として最む基本的であ り，加つ重要な電気絶緣特性の一つである絶縁破罗強

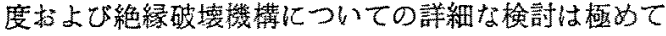
少ない(5)。

著者らは，さきに直流電圧印加時のアルミナ充てん エポキシ樹脂の絶縁破液強度と絶縁破壤機構につき検 討，考察を行なった ${ }^{(6)}$ 。乙の結果，20 100 0 の温度 範囲では空間電荷效果の介在に伴う電子的破垻過程, 100 220 C では純熱破壊過程より説明した。またア ルミナを充てんした場合には，20〜100 $の$ 温度範囲

Electrical Breakdown Characteristics of Alumina Filled Epoxy Resin Under Impulse Voltage. By Noboru Yoshimura, Member, Makoto Nishida, Member (Department of Electrical Engineering, Faculty of Mining, Akita University), Shigetaks Fujita, Member (Hachinohe Institute of Technology), Fumitoshi Noto, Member (Department of Electrical Engineering, Faculty of Mining, Akita University) \& Masayas Tamura, Non-member (Toshiba Chemical $\mathrm{Co}_{0}$ ).

吉社 界：正員，欨田大学鉙山学部露氮工学科

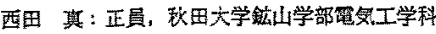

藤田成随：正員，八正工業大学電気工学䅗

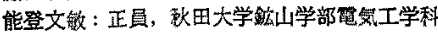

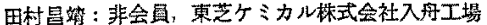

昭 $56-11$
で充てん成粒子界面での電界の上界に伴う破塄を，100 $\sim 220^{\circ} \mathrm{C}$ では界面におけるイオン性空間電荷効果の作 用による破垻として説明した。

本論文では，引き続いて充てん剂粒子と土ポキシ樹 脂界面の効果を検討することを目的に，了ルミナ充て ん工ポキシ樹脂に衝揧電王を印加し，之の際の絶縁破 液特性を謂へた。更に，得られた結果汇基づいて絶縁 破垻機構について考察したので，その結果について報 告する。

\section{2. 試料および実験方法}

〈2.1〉試 料本研究で用いた試料の種類法前 報(6) 之同様ビスフェノールA 形エポキシ樹脂（密度； 1.20 , 比誘電率 $\varepsilon_{1 s} ; 3.0$ ) である。硬化条件结，(115 ${ }^{\circ} \mathrm{C}$ で 15 時間 $+130^{\circ} \mathrm{C}$ で 10 時間)である。表1亿 充てん剂として用いた無水アルミナの諸特性を示す。

実験に用いた試料は充てん剂の部数（樹脂十硬化剂 100 部代対する量) 別では $0,5,40 ， 100 ， 200 ， 250$ 部および 300 部の 7 種類である。7 種類の試料の部数 を体積比 $v_{f}(\%)$ 飞換算した値を表 2 亿示す。表中の 粒子密度 $n$ は, 充て儿粒子 0 平均半径 $2.5 \mu \mathrm{m}$ とし，乙 れが誁料全体伅平等に分有していると仮定した場合の

\section{表 1 無水アルミナの諸特性}

Table 1. Various properties of alumina particle.

\begin{tabular}{|c|c|c|}
\hline 桯 & 類 & 舞水アルミナ \\
\hline 比重 & & 3.95 \\
\hline 虾部電率 & $\varepsilon_{z s}$ & 7.0 \\
\hline 菲 虾 & & 球㫮 \\
\hline 平均嗃径 & $D$ & $=5 \mu \mathrm{m}$ \\
\hline 数庭分布 & & $D=1 \sim 20 \mu \mathrm{m}$, 最大 $50 \mu \mathrm{m}$ \\
\hline
\end{tabular}


表 2 実験に用いた各部数の体積比， 粒子密度，平均粒子間隔

Table 2. Ratio of volume of filler, filler density and average distance of filler for epoxy resin with various alumina parts.

\begin{tabular}{|c|c|c|c|c|c|c|c|}
\hline 諸定数 部 数 & 0 & 5 & 40 & 100 & 200 & .250 & 300 \\
\hline 体秒比 $v_{f}(\%)$ & 0 & 1.5 & 10.8 & 23.3 & 37.8 & 43.2 & 47.7 \\
\hline 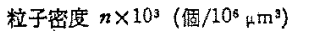 & 0 & 3.57 & 25.4 & 54.68 & 88. 8 & 101.0 & 111.7 \\
\hline 平均柆子閭㜧 $\bar{d}(\mu \mathrm{m})^{*}$ & 0 & 16.2 & 8.4 & 6.5 & 5.6 & 5.3 & 5.2 \\
\hline
\end{tabular}

$100 \times 100 \times 100 \mu \mathrm{m}^{3}$ K含まれる平均㕸子数である。 た平均粒子間隔 $\bar{d}$ は，管極間に平均半径 $2.5 \mu \mathrm{m} \sigma$ 粒子が並えだ昜合の粒子間の距離を示す。

試料形状を図 1 に示す。厚さ $2 \mathrm{~mm}$ の注型板材から 図2 亿示吉過程を経て作成した。試料山歯科医用研摩 器（\#100 のサンドペーパーと同一程度）を用いて研 摩し，所定の擪さとしだ。柘摩の際に生じた切粉を洗 い落とすため，超音波洗浄を 1 時間行なった後，恒温 そうを用いて $60^{\circ} \mathrm{C} ， 2$ 時間の乾燥処理を行なった。 電極は半球一平板とし，両面に導霔性銀ペイントをハ ケを用いて叙布した。電極間の距離は $150 \mu \mathrm{m}$ であ る。なお，厚さ依存性の実験においては $50,100 \mu \mathrm{m}$ 厚さの試料む用いた。試料厚さの测定にはマイクロメ

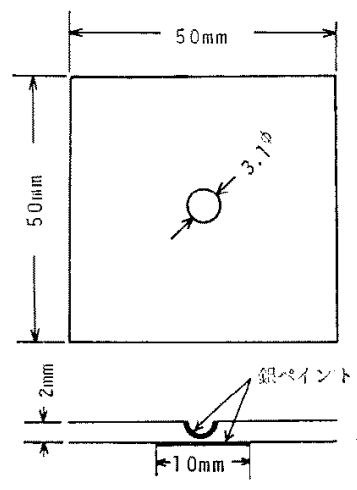

因 1 試料形状

Fig. 1. Shape of sample.

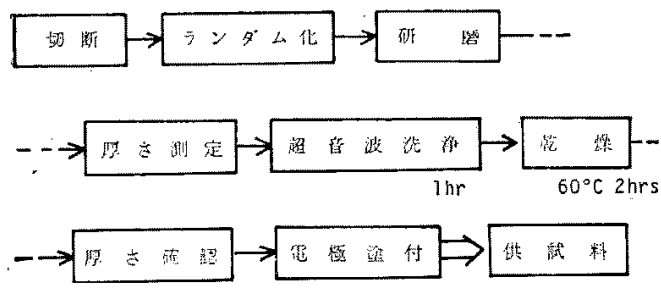

因 2 試料作成過程

Fig. 2. Preparation process of sample.
ータを用いた。

〈2・2〉実験方法衝撃電王は波頭長 $\left(t_{f}\right)$ およよ゙ 波尾長 $\left(t_{t}\right)$ 可変の衝撃電区発生装置を用いた ${ }^{(7)}$ 。本 研究で用いた衝撃電生波形 $\left(t_{f} / t_{t}\right)$ は, 主として $7 / 100$

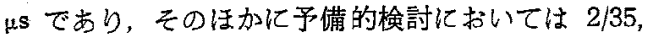
$15 / 190,30 / 400,140 / 1,800 ; 250 / 3,700$ およし $700 / 6,500$

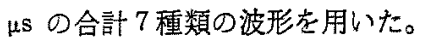

$20^{\circ} \mathrm{C}$ での実験は，10-2 Torr 下で 1 時間脱気好理を 行なった高王トランス油を，60〜220足 の温度範囲に おける実験は，トランス油と同一の条件で脱気処理し たシリコーン油 $(50 \mathrm{cs})$ を周囲媒留として用いた。絶

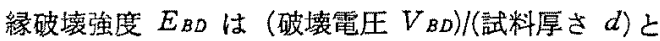
して求的，5〜12 回実験の相加平均值しした。

\section{3. 電圧印加方法および波形を決定する ための予備的検討}

衝揧電圧による破壤詿験における電圧用加方法は， 従来予想破壊電压の少し手前から電王を那加するステ ップアップ方式が多く用いられている(5)。しかし，ス テップアップ方式で実験を進めると，図3に示すよう

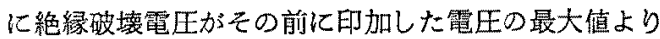
低い值になることが多い。これは前課電により試料に 何らかの形で劣化が伴っているととを示唆し，真の破 壊強度が得られにくいことを意昧する。

そこで図 4 に示すように，予想破㙼電王上り 10〜 10 数 $\mathrm{kV}$ 高い波高值を有する衝摮電圧を明加する， いわゆる過電开方式を用いた予備実験を試みた。実験 に用いた試料形状は図 1 に示すすのであり，250部充 てんのものである。試料厚さは $d=150$ 留 である。 実験方法は〈2.2〉節之同様であり，試娩温度は $20^{\circ} \mathrm{C}$ だる。

困 5 は種々の衝撃電壬波形による絶縁破壊强度の立 上り依存性を，ステップアップ方式上過電圧方式の間 で比較したるのである。ステップアップ方式は初期印

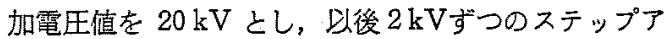

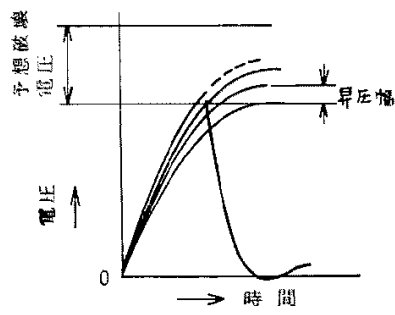

図 3 ステップアップ方式による電压国加 Fig. 3. Applied voltage by means of step up method. 


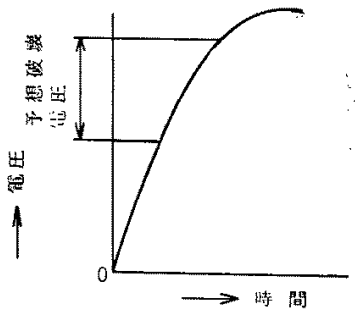

图 4 過電圧方式による電圧印加

Fig. 4. Applied voltage by means of over-voltage method.

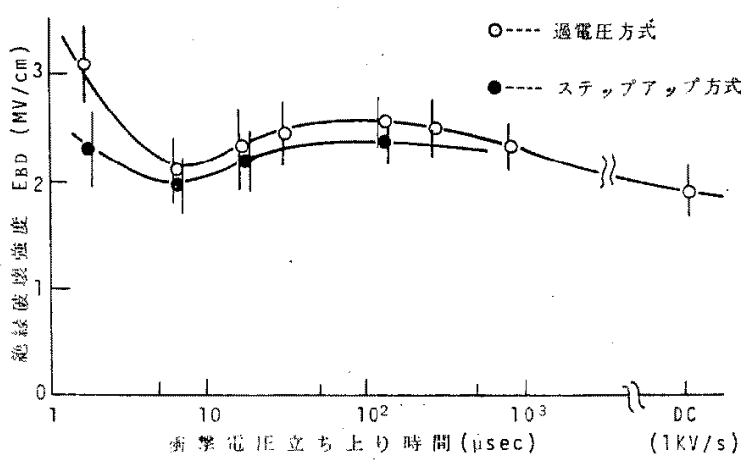

因 5 ステップアップ方式と過電圧方式による 絶縁破塄強度の比較

Fig. 5. Comparison of breakdown strength between step up and over-voltage methods.

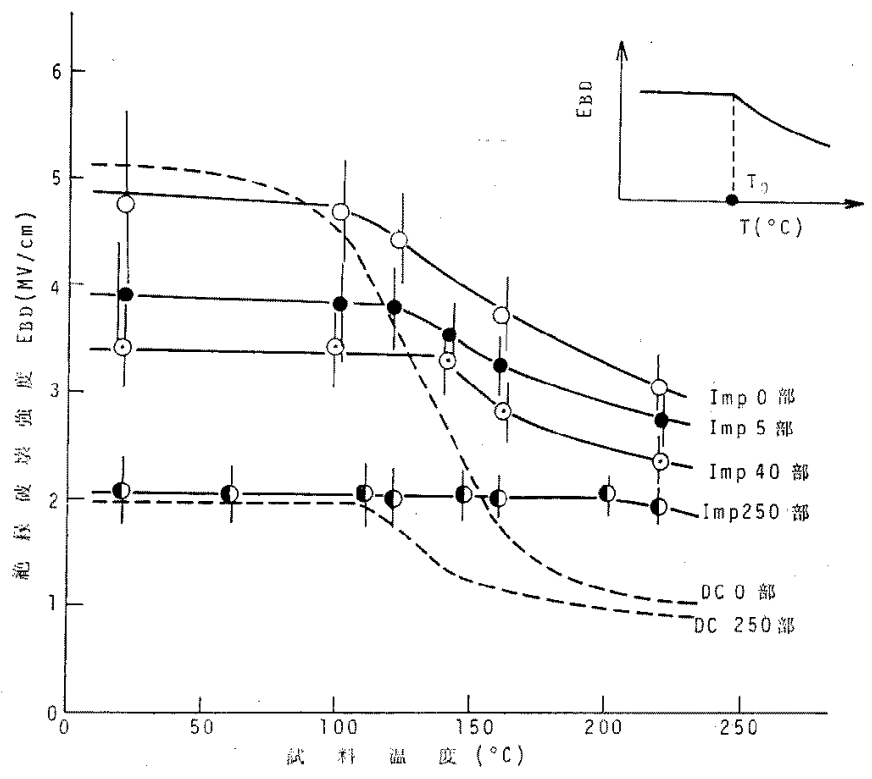

図 6 絶縁破壊強度の温度依存性

Fig. 6. Temperature dependence of breakdown strength.

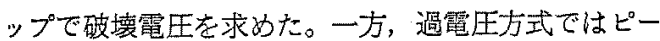
ク值 $V_{p}=50 \mathrm{kV}$ の衝搫電王值を用いた。

ステップアップ方式と過電圧方式の比較をすると， $t_{f}=7 \mu \mathrm{s}$ 以下の短い立入り時間では過電压方式の $E_{B D}$ が高くなるが, $t_{s}=7 \mu \mathrm{s}$ 贝上の長い立上り㭙間では顕 著な差異は認められない。以上の結果より，以後の実 験では前課電の影響を除去できる過電圧方式を，また 狎加電壬波形は $E_{B D}$ が最低值を示す $t_{f}=7 \mu \mathrm{s}$ を採用 した。

なお図 5 の結果によると， $E_{B D}$ は $t_{f}=7 \mu$ おおよび 140 滰にして三つの領域に分けることができる。 すなわち， $t_{j}$ の增加と共に $E_{B D}$ が減少する領域I と
上昇する領域 II, 更に $t_{f}$ の増加と共に直流破墙電圧 に向けて $E_{B D}$ が再び減少する領域 II である。領域工 の傾向を示す原因としては，破壊の時間遅れが推定さ れ(8), 領域 II 甫よび領域 については図 5 と同樣 の結果となる報告むあり ${ }^{(9)}$ ，空間電荷效果之関連して いることが推定されるが，てれらの点についてはここ では澡く触れないととにし，別報にて詳述する予定で ある。

\section{4. 実験結果}

$\langle 4 \cdot 1\rangle$ 絶縁破壊強度 $\left(\boldsymbol{E}_{B D}\right)$ の温度依存性 图6亿充てん部数をパラメータにした $E_{B D}$ の温度 


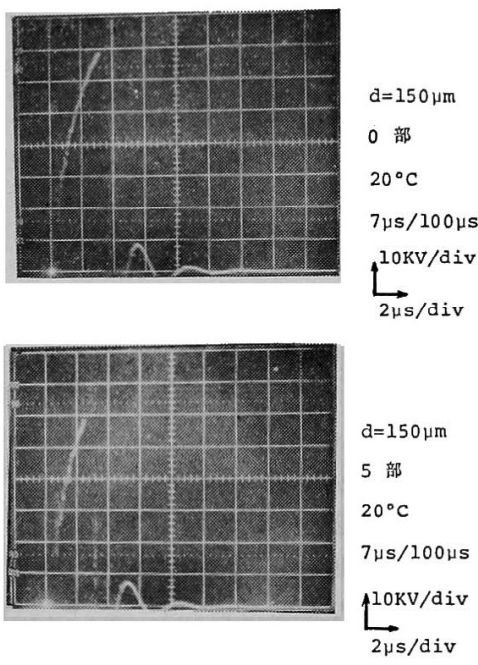

図 7 絶縁破壊した際の電圧波形

Fig. 7. Voltage waveforms in the occurence of breakdown.

依存性を示す。なお参考のため，さきに報告した 0 ， 250 部充てんエポキシ樹脂の直流破壊強度の結果 ${ }^{(6)}$ 併せて示す。過電圧条件は 0,5 部に抢いては $V_{P}$ $=80 \mathrm{kV}, 40$ 部においては $V_{p}=70 \mathrm{kV}, 250$ 部にお いては $V_{p}=50 \mathrm{kV}$ である。試料厚さ $d$ は $150 \mu \mathrm{m}$ である。

衝撃電圧による $E_{B D}$ の温度依存性は, 各部数とも $20^{\circ} \mathrm{C}$ 加 $100^{\circ} \mathrm{C}$ (無充てん), $115^{\circ} \mathrm{C}$ ( 5 部充てん), $145^{\circ} \mathrm{C}$ (40 部充てん), $200 \sim 220^{\circ} \mathrm{C}$ (250 部充てん) の 温度 $T_{0}$ にかけて $\partial E_{B D} / \partial T \simeq 0$ の傾向を持つ領域 $I$ 之, 各々の充てん部数により決まる $T_{0}$ 加 $220^{\circ} \mathrm{C}$ にかけて $\partial E_{B D} / \partial T<0$ の傾向を持つ領域 II に分け ることができる。領域 III に拈ける $E_{B D}$ の低下の割

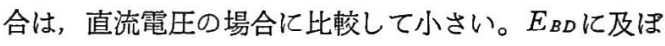
す充てん部数の影響は, 部数が多くなるほど $E_{B D}$ は 全体的に低下する。

0,5 部試料の絶縁破壊した際の電圧波形を図 7 に それぞれ示す。

〈4・2〉絶縁破壊強度 $\left(\boldsymbol{E}_{B D}\right)$ に及ぼす充てん量の 効果四8に試料温度をパラメータ.にした場合の $E_{B D}$ と充てん剂の体積比 $v_{f}$ の関係を示す。過電圧条 件は 0,5 部において $V_{P}=80 \mathrm{kV}, 40,100$ 部におい $\tau V_{p}=70 \mathrm{kV}, 200,250,300$ 部においては $V_{p}=50$ $\mathrm{kV}$ である。試料厚さ $d$ は $150 \mu \mathrm{m}$ で, 衝撃電圧波 形は 7/100 $\mu \mathrm{s}$ である。実験結果を要約すると次のよう になる。

（1）いずれの温度とす， $v_{f}$ が 0 23.3\%（充て ん部数 100 部）にかけて $\partial E_{B D} / \partial v_{f}<0$ の傾向を持

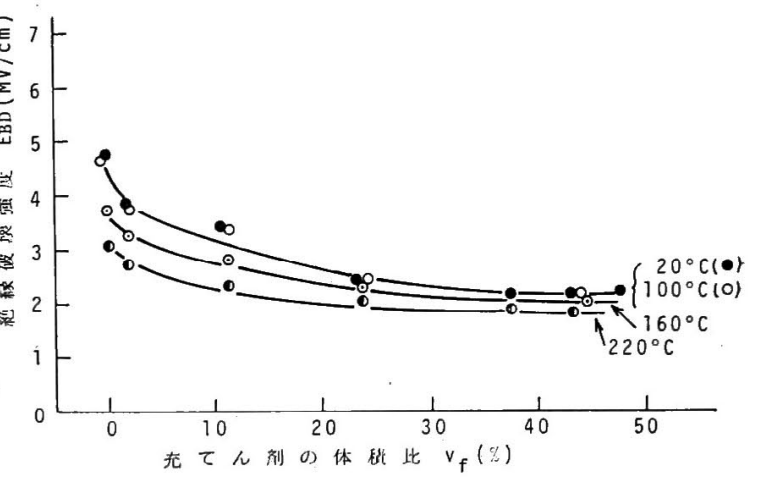

図 8 絶縁破壊強度に抢ける充てん剂体積比の効果

Fig. 8. Effect of volume of filler upon breakdown strength.

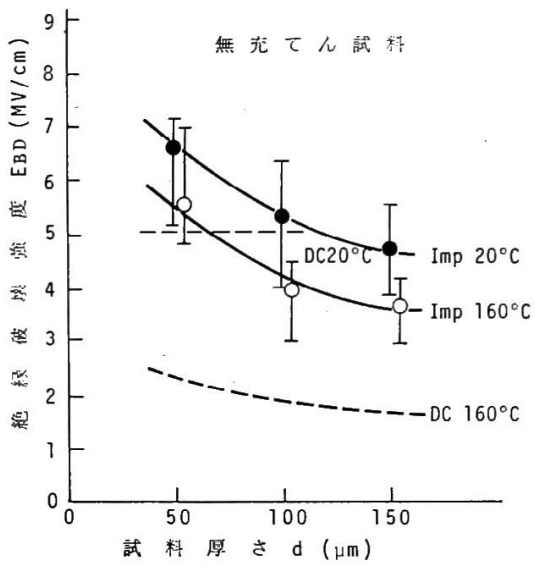

図 9 無充てんエポキシ樹脂の絶縁破壊強度の 厚さ依存性

Fig. 9. Thickness dependence of epoxy resin without filler upon breakdown strength.

つ。一方, $v_{f}$ が $23.3 \%$ (100 部) 47.7\% (300 部) にかけては，ほぽ $\partial E_{B D} / \partial v_{f} \simeq 0$ となる。

(2) 温度の上昇に伴い $v_{f}$ が 0 23.3\% (100 部) の範囲における $\partial E_{B D} / \partial v_{f}<0$ の割合は低下する。

$\langle 4 \cdot 3\rangle$ 絶縁破壊強度 $\left(\boldsymbol{E}_{B D}\right)$ における厚さ依存性

図 9 亿無充てんエポキシ樹脂の試料温度をパラメー タにした衝撃電圧 $(7 / 100 \mu \mathrm{s})$ に上る $E_{B D}$ の厚さ依存 性を示す。参考として直流電圧による結果む併せて示 す。 $20,160^{\circ} \mathrm{C}$ とす $\partial E_{B D} / \partial d<0$ となり, 直流電厌 の場合とは異なる傾向を示す。

図 10 は 250 部充てんエポキシ樹脂の試料温度をパ ラメータにした $E_{B D}$ の厚さ依存性である。 $E_{B D}$ の厚 さ効果は $20,160^{\circ} \mathrm{C}$ 之も無充てんエポキシ樹脂の場合 と同様 $\partial E_{B D} / \partial d<0$ となる。また $20^{\circ} \mathrm{C}$ と $160^{\circ} \mathrm{C}$ で の $E_{B D}$ はほぼ等しい。 


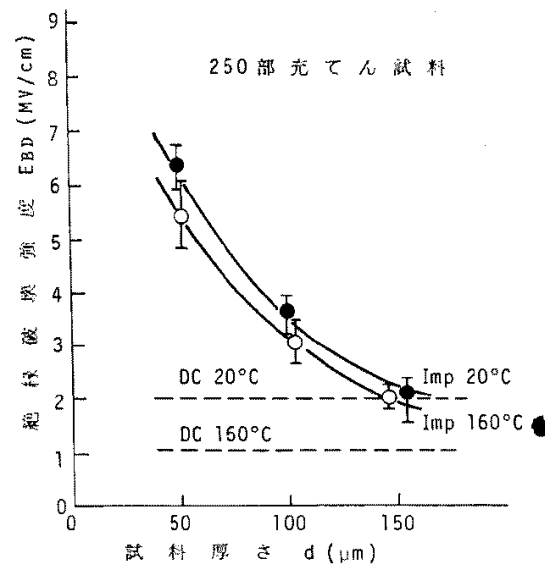

図 10250 部充てえエポキシ樹脂の 絶縁破壊強度の厚さ依存性

Fig. 10. Thickness dependence of epoxy resin with 250 parts filler upon breakdown strength.

\section{5. 実験結果の検討}

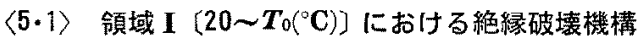
この颃域での絶縁破壊強度 $E_{B D}$ 亿関する諸特性を 整理すると，

(i) $\partial E_{B D} / \partial T \simeq 0$

(ii) $\partial E_{B D} / \partial d<0$

(iii) $\partial E_{B D} / \partial v_{f}<0 \quad\left(v_{f}=0 \sim 23.3 \%\right)$

$\partial E_{B D} / \partial v_{f} \simeq 0 \quad\left(v_{f}=23.3 \sim 47.7 \%\right)$

(iv）破壊までの時間は $2 \sim 7 \mu \mathrm{s}$ （図 7 参照） となる。破壊時間が数 $\mu$ s であることを考慮して，こ の領域に㧍ける絶縁破壊機構としては，定性的には電 子的過程を考えることができる。電子的過程の中で考 えられるものとしては，真性破壊，電子なだれ破㙲，

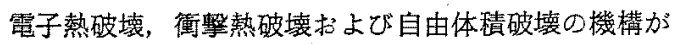
挙げられる(10)(11)。 $\partial E_{B D} / \partial T \simeq 0$ の結果より，電子熱 破壊，衝熬熱破壊，自由体積破壊は考え難く，真性破 壊では $E_{B D}$ の厚さ効果 $\left(\partial E_{B D} / \partial d<0\right)$ を説明する こ上が難しい。 $\partial E_{B D} / \partial T \simeq 0, \partial E_{B D} / \partial d<00$ 実験結 果を考慮に入れると，との領域に抬ける過程としては 電子なだれ破燷機構を考えるととができる。この場 合，充てん剂が分散して存在する匀一でない系に対し て電子なだれ破堎理諭を適用した報告はなく，電子な だれ破壊理諭の適用の罗当性については明白でない。

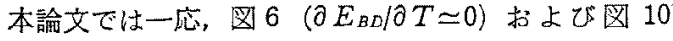
$\left(\partial E_{B D} / \partial d<0\right)$ の結果基ついて充てんエポキシ樹脂 についてす電子なだれ破壊理論を適用する。

簡学のため，単一なだれにおける Seitz 氏の 40 世 代理論(12)を用いて実験結果を検討する。この理諭に

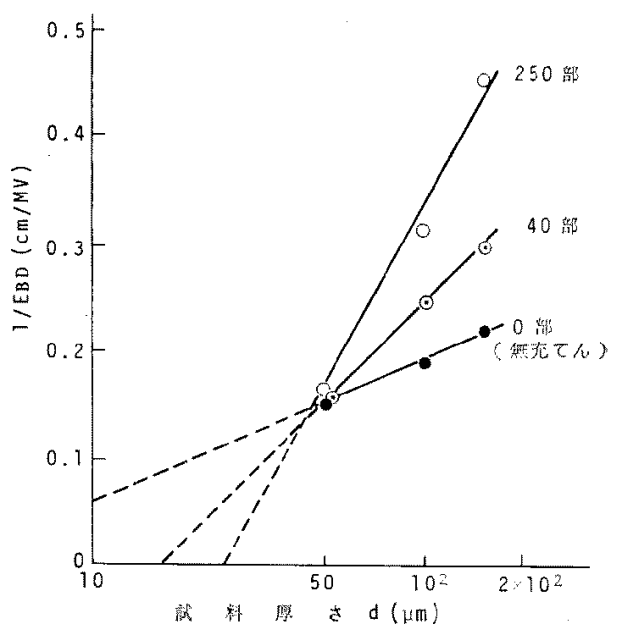

図 $11\left(1 / E_{B D}\right)$ 亡試料厚さの関係

Fig. 11. Relation between $1 / E_{B D}$ and thickness of sample.

上れば，試料厚さが $d$ であるときの $E_{B D}$ は次式で与 えられる(13)。

$$
E_{B D}=H / \ln (d / 40 \lambda)
$$

ここで

$$
H=\left(\frac{m}{2 e^{2}}\right)^{1 / 2} \int_{\varepsilon_{a \nu}}^{I} \frac{d \varepsilon}{\sqrt{\varepsilon \bar{\tau}(\varepsilon)}}
$$

ただし， $\bar{\tau}(\varepsilon):$ エネギー $\varepsilon$ を有する電子 の平均箸突時間， $I:$ イン化エネルギー, $\varepsilon_{a v}:$ 自由電子の $t=0$ におけるエネルギー,

$e:$ 電荷量, $m:$ 電子質量, $\lambda:$ 電子の平均 自由行程

また，電界が $E$ でるときの電子の移動度 $\mu$ は 次式で求まる。

$$
\mu=(e \lambda / m)^{1 / 2} E^{-1 / 2}
$$

以上のことを基礎しし，実験結果加ら $H ， \lambda$ およ び $\mu$ の推定を次に行なう。まず，(1)式変形して

$$
1 / E_{B D}=(1 / H) \ln d-(1 / H) \ln 40 \lambda
$$

ŁL $, y=1 / E_{B D}, a=1 / H, x=\ln d, b=(1 / H) \ln 40 \lambda$ と报くと，(4)式は簡単に

$$
y=a x-b .
$$

と表わせる。往って，yとx の関係夲プロットし， その直線の傾きと $y$ 切片とから， $H$ 执よず $\lambda$ の值 を求めることができる。

図 11 K $0 ４ 0 ， 250$ 部充てん試料の実験結果加ら 求めた $1 / E_{B D}-\ln d$ の関係寺示。同図加ら、およ びるを読み，(5)式の諸関係式加ら $H$ および $\lambda$ を 求めると表 3 に示すような結果を得る。更に(3)式よ 
表 $3 H, \lambda$ お术 $\mu$ の值

Table 3. Values of $H, \lambda$ and $\mu$.

\begin{tabular}{|c|c|c|c|c|}
\hline \multirow{2}{*}{ 锗定数 } & \multicolumn{3}{|c|}{ 工 ポ キ } & \multirow{2}{*}{$\begin{array}{l}\text { ポリエチレ } \\
\text { ソ(14) }\end{array}$} \\
\hline & (部部九) & 40 部 & 250 部 & \\
\hline$H(\mathrm{MV} / \mathrm{cm})$ & 18.4 & 6.1 & 3.2 & 20.0 \\
\hline$\lambda(\AA)$ & 750.0 & $5,552.0$ & $8,882.0$ & 250.0 \\
\hline$\mu\left(\mathrm{cm}^{2} / \mathrm{V} \cdot \mathrm{s}\right)$ & $51.0 * 1$ & $154.9 * 2$ & 279. $3^{* 8}$ & $27.0 * 4$ \\
\hline
\end{tabular}

$* 1: E=5 \mathrm{MV} / \mathrm{cm}, * 2: E=4 \mathrm{MV} / \mathrm{cm}$

$* 3: E=2 \mathrm{MV} / \mathrm{cm}, * 4: E=6 \mathrm{MV} / \mathrm{cm}$

り $E=5 \mathrm{MV} / \mathrm{cm}$ (無充てんの場合)， $E=4 \mathrm{MV} / \mathrm{cm}$ (40 部充てん)，E=2MV/cm (250 部充てん) にお 吋るそれぞ㧈の移動度 $\mu$ の計算結果む併せて表了に 示す。な敊，充てえ部数比より $E$ 加異なるのは破槡 電界強度を用いたためである。以上の結界は，電子な だれ破填理諭を滴用するときの条件 ${ }^{(13)}$

$$
d>2.72 \mu H \tau i\left(\tau=\frac{m}{e} \mu\right)
$$

を十分満足している。ただし $i=40$ である。

現在 $H, \lambda$ および $\mu$ の值に関して無充て九および 充てんエポキシ樹脂についての信賴すべき実験結果が 見あたらないので，その罗当性については十分な检討 が不可能である。しかしながら，表 3 に示す上うに本 研究で得られた無充てんエポキシ樹脂についての $H$, $\lambda$ および $\mu$ の諸量とポリエチレンにつき調べた諸 量(14)の比較をすると，值方接近しており不合理でな い上うに思机る。

充てん剂の混入により電子の平均自由行程 $\lambda$ は表 3 に示したように大きくなる。てれは図 12 に示すよう に，粒子界面では集中電界 ${ }^{(16)}$ のために電子の加速度 が大きくなり，なだれの成長むそれに伴い大きくなる ためと考无られる。

その他としては，粒子の界面付近を通るなだれ電子 が界面の弱点をぬって急激に成長する過程む考えられ る。充てん剂入りエポキシ樹指でのトリーの進展は， 樹脂と粒子の界面が電気的弱点になって，トリーがて の界面を伝わって伸びて行くという報告(3)があること より，界面近傍での急激ななだれ成長は十分可能性の ある過程であると思われる。

$\langle 5 \cdot 2\rangle$ 領域 II $\left(\boldsymbol{T}_{0} \sim 220^{\circ} \mathrm{C}\right)$ における絶縁破壞機構 この領域に招ける $E_{B D}$ の諸特性を整理するこ

(i) $\partial E_{E D / \partial T} T<0$

(ii) $\partial E_{B D} / \partial d<0$

(iii) $\partial E_{B D} / \partial v_{f}<0 \quad\left(v_{f}=0 \sim 23.3 \%\right)$ $\partial E_{B D} / \partial v_{f} \simeq 0 \quad\left(v_{f}=23.3 \sim 47.7 \%\right)$

（iv）破壊までの時間は $2 \sim 6 \mu \mathrm{S}$ （破壊時の電圧波 形は図 7 と同様)

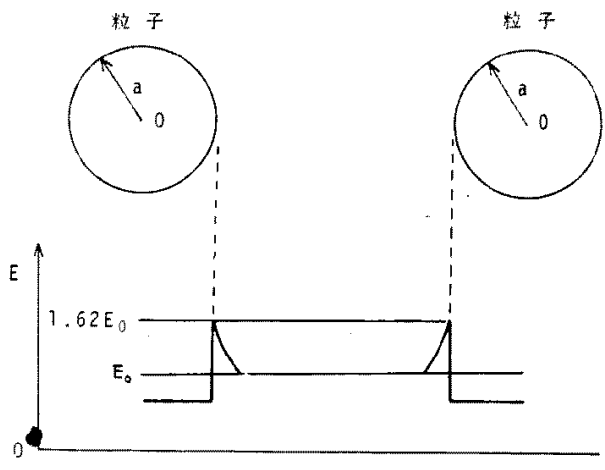

図 12 粒子間の笔界分布

Fig. 12. Electric field distribution between particles.

となる。この領域では〈5.1 節と同様, 電在印加開始 加ら破壊に至るまでの時間が $2 \sim 6 \mu \mathrm{s}$ 之極めて短いて 之加ら, 考えられる絶緑破罗の過程としては電子的過 程を挙げることができる。

まず，実験結果（i）の $\partial E_{B D} / \partial T<0$ の温度传存 性を説明する過程として電子熱破壊を挙り゙るとする 之，乙の機棈では実駼結果（ii）の $\partial E_{B D} / \partial d<0$ を 説明することが困難であり否定的である。電子なだれ 破壊僟構とすると（苗）の $\partial E_{B D} / \partial d<0$ の結果を説 明できても，一方で（i）の $\partial E_{B D} / \partial T<0$ の温度依 存性の説明が困難である。また，衝揧熱破壊機構を考 える上， $\partial E_{B D} / \partial T<0$ が説明できても $\partial E_{E D} / \partial d<0$ の説明か涃難となる。数 $\mu \mathrm{s}$ 程度の破塄時間では定常 熱破壊む考え難い。この領域での最も可能性の市る絶 縁破壊機構としては自由体皘破壊(11)が考元られる。 自由体皘破塄は高分子に適用されるもので，分子運動 により自由体皘が集積して空孔が生成し，電界方向に 並ふため空孔内での電子の加速により絶緑破壊が起こ るとの考えである(11)(15)。エポキシ樹脂中の自由体積 はガラス転移点温度以上で增加し，それに伴い絶緑破 塄強度の低下が報告されている(16)。本研究で用いた ビスフェノールA 形エポキシ樹脂のガラス䎐栘点温 度は 110 120 $0^{\circ} \mathrm{C}$ であり，図6に示したように無充て んエポキシ樹脂の衝撃電Eによる絶縁破壊強度 $\left(E_{B D}\right)$ の低下する温度に対忍している。

一方，アルミナ充てんエポキシ樹脂の場合にも，無 充てんエポキシ樹脂の場合と同様エポキシ樹脂中での 温度上昇化伴う自由体皘の増加加，絶縁破填強度を低 下させるむのと考えられる。図6に示したように，無 充てんエポキシ樹脂の場合には $100^{\circ} \mathrm{C} よ り E_{B D}$ は低 下を開始するのに対し，5部充てん試料ては $115^{\circ} \mathrm{C}$ よ り，40 部充てん試料では $145^{\circ} \mathrm{C} よ り ， 250$ 部充てん 


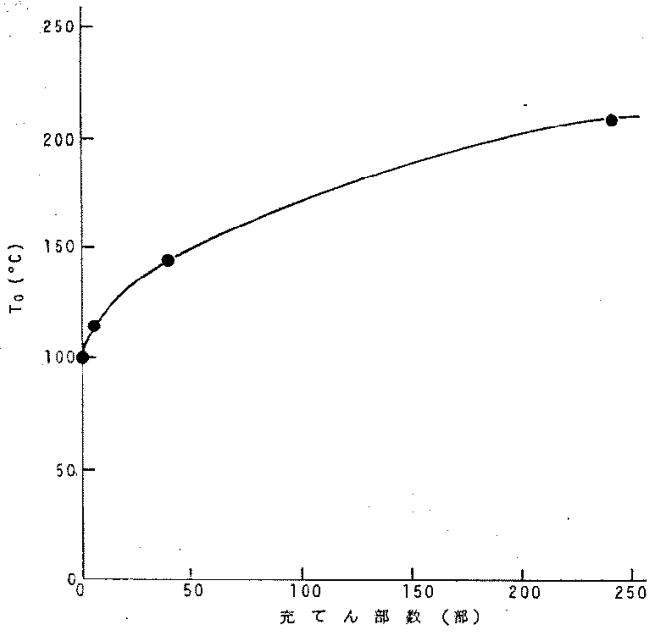

図 13 充てん部数と $T_{0}$ の関係

Fig. 13. Relation between filler parts and $T_{0}$.

試料では 200〜 $220^{\circ} \mathrm{C}$ より低下を開始している。すな わち，アルミナを充てんすることにより， $E_{B D}$ の低下 童開始する温度 $\left(T_{0}\right)$ 加高温部へ移行する。充てん部 数と $T_{0}$ の関係在 13 K示す。との $T_{0} の$ 高温部へ の移行は，アルミナ粒子を充てんするととにより，温 度上昇に伴うエポキシ樹脂中での自由体積の増加が抑 えられるためと推測される。例えば 250 部充てん試料 の場合には，全体積の約 $45 \%$ がてルミナ粒子により 占有さ就ており，この場合温度上昇に伴うエポキシ樹 脂中での自由体積の增加する割合が無充てん捛よび 5 部，40 部充てん試料に比較して少なくなるため，200 ${ }^{\circ} \mathrm{C}$ 程度まで $\partial E_{B D} / \partial T \simeq 0$ の特性になるむの上考光ら れる。

以上，領域 II においては温度上昇に伴う自由体積 の増加から破塆機構を検討した。このほかにも，充て ん阂一樹脂界面の化学的ならびに物理的不整（例え は密着不良，気層の存在など）にるるとも考えられ る。確加に長時間寿命特性の場合には, 界面の化学 的，物理的不整が大きな影響を持つことが郝告されて いる(3)。仮に本実験の場合にも，界面における化学 的，物理的不整加影響するあの上すると，充てん部数 の多い試料ほよ゙温度上昇に伴い化学的，物理的不整力 增加し，絶縁破壊強度 $\left(E_{B D}\right)$ の低下は大きいものと 予測される。园 6 の結果より， $20^{\circ} \mathrm{C}$ 上 $230^{\circ} \mathrm{C}$ におけ るそれたれの $E_{B D}$ の比をとると

無厺てん： $E_{B D}\left(230^{\circ} \mathrm{C}\right) / E_{B D}\left(20^{\circ} \mathrm{C}\right)=0.67$

5 部充てん: 0.74

40 部范てん: 0.74

250 部充てん: 0.95
しなり，立てん部数の多いはご温度上昇に伴う $E_{B D}$ の低下が小さい。この結果より，数 $\mu \mathrm{s}$ 程度で破壇す

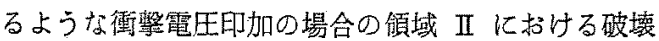
は，界面上りも樹脂中の自由体樻の堌加力゙破䘫の大き な要因と考えた。

なお，領域 II におりる直流電生による $E_{B D}$ の温 度依存性は，図6に示したように衝撃電生の場合に比 較して $E_{B D}$ の低下の㹕合が大きい。この場合の絶縁

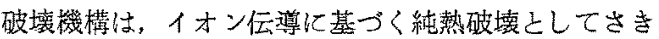
に報告した(6)。

\section{6. あとがき}

衝撃電圧 $(7 / 100 \mu \mathrm{s})$ をビスフェノール $A$ 形エポキ シ樹脂に印加したときの絶縁破壇強度 $\left(E_{B D}\right)$ に及ぼ すナルミナ粒子の影饗を， $E_{B D}$ の温度依存性，厚さ依 存性，志て几部数依存性より检詂した。てして得られ た結果に基づいて，二つの領域に扣ける絶縁破買機構 を考察した。

頜域 I $\left(20^{\circ} \mathrm{C} \sim T_{0}\right)$ (なお， $T_{0}$ は無充てんで 100 ${ }^{\circ} \mathrm{C}$ ，5部充てんて $115^{\circ} \mathrm{C} ， 40$ 部充てんで $145^{\circ} \mathrm{C}, 250$ 部充てんで $200 \sim 220^{\circ} \mathrm{C}$ である) 扰頑域 II (T。

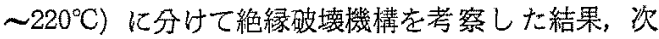
のことが得られた。

領域 I $の$ 絶縁破塆機構としては, $\partial E_{B D} / \partial T=0$,

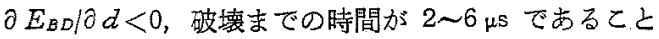
より電子なだれ破塆により説明される。充てん剂の混 入により絶縁破壤強度 $\left(E_{B D}\right)$ の低下する原因之して は，粒子界面における集中電界により電子の加速度が 大きくなり，なだれの成長を促進するためと考えられ る。

一方，領域求いては $\partial E_{B D} / \partial T<0, \partial E_{B D} / \partial d$

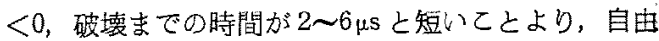
体積破壤によるむの上して䒓察した。温度上昇に伴う エポキシ樹脂中の自由体積の増加と集中電界の作用が 重量し，絶縁破買強度 $\left(E_{B D}\right)$ を低下させる委の上考元 られる。充てん斉の湿入は，温度上昇に伴う自由体皘 の堌加定抑制し，その結果 $E_{B D}$ の低下を開始する温 度 $\left(T_{0}\right)$ を高温側に移行させるものと考えられる。

最後に，本研究に対し微拹力下された秋畞大学大学 院生 蛇沢勝英君 (現在，大日本インキ化学)，同電気 工学科高橋重雄技官に䚴意を表す。

(昭和 56 年 1 月 29 日受付，同 56 年 7 月 17 日再受付)

\section{文献}

(1) H. Honjo, W. Toyoshima, M. Tamura \& N. Kawamura "Short and Long-Term Strength Characteristics of 
Particulate-Filled Cast Epcxy Resin", Polymer Engi" neering Science, 14, 604 (1974)

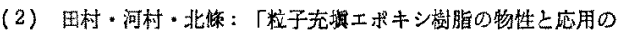

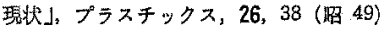

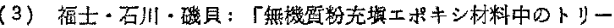
と $V-t$ 特性」，電気学会绝縁材料研資 IM-73-36 (晒 48)

(4) T.W. Dakin: "Application of Epoxy Resin in Electrical Apparatus ", IEEE Trans. Elect. Insulation, EI-9, $121(1974)$

(5) R. Lovell: "The Effect of Specimen Size on the Elect. ric Breakdown of Unflled and Filled Epoxy Polymer" ivid., EI-11, 110 (1976)

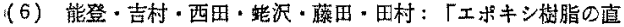

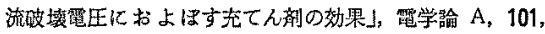
109 (晒 56-2)

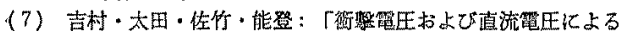
叔エチレン中のトリーの発生」, 同上 A，96，433（昭 51 $-9)$

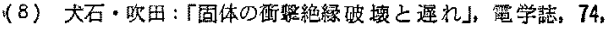
150 (昭 29-2)
(9) D.B. Watson: "The Electric Strength of Perspex as a Function of Voltage Rise Time", J. Phys, D: Appl. Phys., 5, 410 (1972)

(10) J.J. O'Dwyer: The Theory of Electrical Conduction and Breakdown on Solid Dielectrics (1973) Clazendon Press, Oxford

(11) J. Artbauer: Zur Temperaturabhängigkeit der Elektrischen Durchschagtestigkeit amorpher Polymeren mit Relaxation unter der Glástemperatur", J. Polymer Science, Part C, No.. 16, 477 (1967)

(12) F. Seitz: "On the Theory of Electron Multiplication in Crystals", Phys. Rev., 76, 1376 (1949)

（13） 犬石・中島・川辺・家田：誘笛体現象猃，p. 293 (昭 48) 電気学会

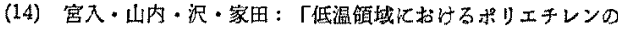

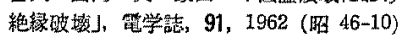

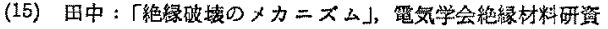
EIM-80-65 (昭 55)

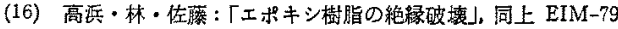
$-26($ 昭 54$)$ 